\title{
VALUE-ADDED AGRICULTURAL BIO-BUSINESS DEVELOPMENT IN EUROPEAN COUNTRIES
}

\author{
${ }^{1}$ Jolita Greblikaitè, ${ }^{2}$ Judita Astrovienè, ${ }^{3}$ Deimena Montvydaitė \\ ${ }^{1}$ Assoc. prof. Vytautas Magnus University, K. Donelaičio 58, Kaunas, Lithuania, \\ Email address jolita.greblikaite@vdu.lt \\ ${ }^{2}$ Vytautas Magnus University, K. Donelaičio 58, Kaunas, Lithuania,Email address judita.astroviene@vdu.lt \\ ${ }^{3}$ PhD candidate Vytautas Magnus University, K. Donelaičio 58, Kaunas, Lithuania, \\ Email address deimena.montvydaite@vdu.lt
}

\begin{abstract}
The aim of the paper is to analyse value added agricultural bio-business trends and its development perspectives in Europe. The research includes theoretical insights of value-added bio-business, value-added agriculture bio-business trends and development opportunities, comparing value added statistical tendencies in European countries, exploring the perspectives of agricultural bio-business development. Two billion tons of biomass are made in Europe yearly. In total biomass intake $44 \%$ is used for feed, $21 \%$ for food, $19 \%$ for processing and $12 \%$ for energy production (Lovric et. all., 2020). The research reveals that gross value added at current prices in European Union has an increasing tendency, according to 2010-2018 data as well as gross value added of the agricultural production at basic prices at the period 20082019. Most European countries have a potential for value added agricultural bio-business development. Lithuania, Poland, and Netherlands have different political, economic, socio-cultural, and technological environment and its conditions for bio-business development, but they are tending to be positive in terms of value-added agricultural bio-business.

Keywords: agriculture, bio-business, gross value added, value added bio-business.

JEL codes: Q16, M10.
\end{abstract}

Received 2806 2020; Accepted 01092020

\section{Introduction}

The bioeconomy provides a wide range of public goods, in particular rural and coastal jobs, sustainable future food and energy supplies and conservation of natural environments and biodiversity, as well as contributing to economic growth while providing investors with a financial return (European Technology Platforms, 2017). Bioeconomy refers to the sustainable production and conversion of biomass into a range of food, health, fibre and industrial products and energy. Renewable biomass encompasses any biological material (agriculture, forestry and animal-based including fish) as a product or to be used as raw material. As the world is currently facing abrupt climate changes, land and ecosystem degradation and the scarcity of resources coupled with a growing population (Bikse et al., 2019), Europe must try to ensure a safe, healthy, and prosperous environment for current and future generations. Successfully addressing major environmental, social, and economic challenges will change the way we live and work. The bioeconomy will make this a change for the better if its potential for sustainable production and conversion of biological material is fully exploited.

The mature, sustainable bioeconomy will help deliver global food security, improve nutrition and health, create smart bio-based products and biofuels, and help agriculture, forestry, aquaculture, and other ecosystems to adapt to climate change. The integrated bioeconomy is not simply about science but is rather an integration of science with business and society (European Technology Platforms, 2017). The decline in natural resources, population growth, climate change and other global and economical challenges in recent years have encouraged the traditional economy transfer into a bioeconomy. Bioeconomy refers to the sustainable production and conversion of biomass into a range of food, health, fibre and industrial products and energy.

Copyright (C) 2020. Published by Vytautas Magnus University. This is an open access article distributed under the terms of the Creative Commons Attribution Non-Commercial 4.0 (CC BY-NC 4.0) license, which permits unrestricted use, distribution, and reproduction in any medium provided the original author and source are credited. The material cannot be used for commercial purposes. 
The integrated bioeconomy is not simply about science but is rather an integration of science with business and society (European Technology Platforms, 2017). According to the OECD, biobased economy by 2055 will be the main driving force of the European economy, with a special focus on agriculture (Lietuvos ... santrauka, 2017). Multifunctional, value-added, and biotech-based businesses have become increasingly viable, as it can help key sectors of the economy (agriculture, health, etc.) solve the problems of limited resources, environmental concerns and more (Vilmantas, Melnikas, 2014). It is evident that in the international market (USA, EU) further economy growth plans will focus on bio-business (Hassan et al., 2015).

Future science and policy programs expect companies to adopt business models, based on the circular economy and providing added-value (Leipold and Petit - Boix, 2018). Industries and business organizations are expected to be pivotal to the development of both the circular economy and the bioeconomy, and to contribute to the Sustainable Development Goals of the UN 2030 Agenda (D'Amato et al., 2020). There was created almost 190000 million euro of gross value added of the agricultural production in European Union. The biggest amount of gross value added of the agricultural production in 2019 was created in Italy (31 867 million euro), France (31 027 million euro), Spain (26 465 million euro), Germany (21 060 million euro). Therefore, it is appropriate to further analyse the development of high value-added agricultural bio-business.

Purpose: the aim of the paper is to analyse value added agricultural bio-business trends and its development perspectives in European countries.

Object: value-added agricultural bio-business.

Research methodology. Research is based on scientific works analysis in the value-added agricultural bio-business, which provides the importance of macro environment analysis for the conditions of such kind business development in European countries. The analysis of the strategical trends and tendencies for agricultural bio-business will provide political and legal initiatives in EU countries. Economic data analysis will provide numbers of existing and supportive business for agricultural biobusiness development. Technological environment analysis provides the technology and scientific potential, technical based conditions for bio-business in the countries. Sociocultural environment of the countries provides important insights about society and its social climate for bio-business creation and bio-products consumption.

The PEST analysis is made for such countries as Lithuania, Poland, and Netherlands. These countries for analysis are selected because is presumed that those countries are different in development level in bio-business, especially agricultural bio-business. The comparative analysis does not seek necessary to rank countries due to all criteria. The aim is to provide the status quo and the existing conditions for value-added agricultural bio-business development and present potential trends for improvement. Methods of research are scientific literature analysis in-depth, macro environment analysis (PEST), document analysis, statistical data analysis, comparative analysis.

\section{Theoretical background and insights}

Bio-business and its problems are widely discussed in scientific literature. However, there is no well-established definition of bio-business phenomenon. It is treated differently by different authors. Theoretical works, research and even legislation in different countries name the bio-business differently and analyse it from the different angles: research of the bioeconomy (Arujanan and Singaram, 2018; Bikse at al., 2019; D’Amato et al., 2020), biotechnology (Gunn, 2016; Timmis et al., 2017; Hayward et al., 2017; Arujanan and Singaram, 2018; Sabrewal, 2018 et al.), biotechnology business models (Niosi and McKelvey, 2018; Tyagi et al., 2018; Horvath, 2019 et al.) and other insights.

According to Gunn (2016), bio-entrepreneurship is entrepreneurship principles applied to the business value propositions of the biotechnology industry. Bio-business is inseparable from the technology and processes underlying it. In this work, bio-business is understood as a business involving 
the use of biological processes in the energy, forest, agricultural or chemical industries and transforming natural resources into goods or services. It is important to mention that to maximize added value, bio business's material for semi-finished products or final products needs to be treat as much as possible.

All bio-businesses can be perceived as certain processes consisting of five main stages that are research, development, testing/registration, production, and marketing (Kiskis and Limba, 2016). Biotechnology-based business is often divided into the following branches due to its interdisciplinarity (Kafarski, 2012):

- Green (agriculture): GMO development and others.

- Blue (marine organisms): application of molecular and biological processes in underwater technology.

- Red (health care): use of proteins, enzymes, living organisms and other substances to treat diseases, gene testing, etc.

- White (industrial and environmental): use of enzymes and micro-organisms in chemicals, textiles, etc.

- Purple (intellectual property): patents, scientific publications, inventions.

- Yellow (food and supplements).

- Gold (nanotechnology, bioinformatics, genetic engineering).

- Brown (arid and desert organisms).

- Gray (classical fermentation).

- Black (bioterrorism and biological weapons).

It can be concluded that bio-business is differently treated phenomenon in scientific literature. It depends on the research area. Despite the complexity of definition, it can be summed up that bio-business relates to natural resources and can be perceived as certain processes consisting of main stages: research, development, testing/registration, production, and marketing. This article focuses on green or agricultural bio-business and its development in European countries.

The notion that perpetual economic growth of traditional business sectors is possible and sustainable is unrealistic. The central task is thus to focus strategic economic development investment in new business growth sectors that most effectively and sustainably inter alia increase productivity, streamline consumption and scale down waste, in order to create a healthy economic growth trajectory within the global context (Timmis et al., 2017). The development of bio-businesses makes a significant contribution to the international economy and creates added value. The global biotech market has been growing in recent years, reaching around $\$ 250$ billion USD in 2019, it can be assumed that growth will continue (Bumelis, 2018).

Analysing bio-business trends internationally, it could be seen that there are three largest biotech markets in the world: the US (45.5\%), Europe (28.8\%) and Asia (24\%). But not only markets, also individual countries are seen in the international context. The strongest countries dedicate at least $2 \%$ of GDP to R\&D, provide business support and develop innovation-friendly policies (Biotechnology ... country, 2019). The red and green branches are the most promising for development in the international market. The leading fields of the development of biotechnology is agricultural (plant research, food, and feed) and medical bio-businesses.

EU bioeconomy is expected to develop rural and regional bio-businesses. Although rich in biomass, rural areas are characterized by lower levels of entrepreneurship. It is feared that urban areas with higher potential for innovation will produce higher value-added products, while rural and regional areas will only supply biomass (Tetslaff and Clifford, 2019). Companies of all sizes participate in the bioeconomy, and entrepreneurship structures are different at the various scales.

Although continuous knowledge development is still crucial to successful innovation for all companies, novel cooperation models are needed to allow different business models to be used collaboratively to boost the development of the bioeconomy (European Technology Platforms, 2017). Focusing on agriculture bio-business, the experience of other countries shows that it is useful to 
switch from traditional agriculture to multifunctional and high value added (e.g. cultivating, several times processing and selling online) (Negoro, 2018). Businesses will have to undergo significant change if they are to compete successfully in the future bioeconomy against new companies being formed in the sector today. Such transformations can be uncomfortable and carry a higher risk in the short term. However, unless they move from their comfort zone, they risk becoming uncompetitive as the bioeconomy develops around them (European Technology Platforms, 2017). High added agricultural bio-businesses could target biodiversity, pollution control, nature and landscape conservation, and development of bio-business in less-favoured areas.

\section{Research results}

Analysing value-added agriculture bio-business development, it is important to look over farm structure trends, to estimate whether European countries including agriculture sector into bioeconomy strategies, to evaluate total gross value-added trends in Europe and gross value added of the agricultural production and to foresee the perspectives of its further development.

There is a change in the consumption of farm products in the international context - growing need for multifunctional, sustainability and high added value. The European Union, Japan, Korea, Norway, Portugal and Switzerland declare that agriculture not only has to produce agricultural commodities, foodstuffs, but also to develop new innovative technologies, as well as to create higher added value, simultaneously produce multifunctional raw materials and products (Lainez at al., 2018). The following changes in the structure of the farm are forecasted in Table 1.

Table 1. Structure of the farm (adapted according Lainez at al., 2018)

\begin{tabular}{|c|c|c|}
\hline Specification & $\mathbf{2 0 2 0}$, thousand & 2030, thousand \\
\hline$<1$ ha & 1468,5 & 1258,5 \\
\hline $1-5$ ha & 787 & 591,5 \\
\hline $5-20$ ha & 523 & 447,5 \\
\hline $20-50 \mathrm{ha}$ & 120 & 146,2 \\
\hline $50-100 \mathrm{ha}$ & 29 & 56 \\
\hline $100-300 \mathrm{ha}$ & 8,8 & 16,2 \\
\hline $300-500 \mathrm{ha}$ & 0,4 & 0,6 \\
\hline $500-1000 \mathrm{ha}$ & 0,2 & 0,3 \\
\hline$>1000 \mathrm{ha}$ & 0,1 & 0,2 \\
\hline Average farm area & $\mathbf{9 , 2}$ ha & $\mathbf{1 0 , 7}$ ha \\
\hline
\end{tabular}

As can be seen in Table 1, there is a tendency that the number of very small farms (up to 1 ha) will decrease significantly. The average area of the farm is growing. This means that larger areas are open to more activities. Although the total number of farms will decrease, the area occupied by farms will increase. It can be assumed that there is a possibility for farms to connect and transform into multifunctional farms. Whereas the value added is analysed in the context of bioeconomy, it is important to estimate what sectors includes into bioeconomy strategy in European Union, ephasizing agriculture sector (Table 2). 


\section{Table 2. Sectors included into bioeconomy strategy and monitoring in the European Union (compiled by the authors based on the data of Food and Agriculture Organization of the United Nations, 2018)}

\begin{tabular}{|l|c|c|c|}
\hline Sectors & $\begin{array}{c}\text { Included into bi- } \\
\text { oeconomy strat- } \\
\text { egy }\end{array}$ & $\begin{array}{c}\text { Included into bioecon- } \\
\text { omy strategy and moni- } \\
\text { tored or measured }\end{array}$ & $\begin{array}{c}\text { Not included into bio- } \\
\text { economy strategy }\end{array}$ \\
\hline Agriculture & + & + & - \\
\hline Automotive and mechanical engineering & - & + & + \\
\hline Chemistry (incl. bioplastics) & + & + & - \\
\hline Biofuels/ bioenergy & + & - & + \\
\hline Biorefining & - & - & + \\
\hline Construction/ Building industry & - & - & + \\
\hline $\begin{array}{l}\text { Consumer goods such as cosmetics and } \\
\text { cleaning products }\end{array}$ & - & + & - \\
\hline Feed & + & + & - \\
\hline Fisheries & + & + & - \\
\hline Food and Beverage industry & + & + & - \\
\hline Forestry & + & - & + \\
\hline Health & - & - & - \\
\hline Knowledge/ Innovation & + & - & + \\
\hline Mining & - & + & - \\
\hline Pharmaceuticals industry & + & + & - \\
\hline Pulp and paper & + & + & - \\
\hline Textiles & + & & \\
\hline
\end{tabular}

Value-added agriculture bio-business is an important direction for future value-added creation. Analysis revealed that Europe generates significant amount of value added, that value added in agriculture sector is also important and, as it was argued by theoretical insights, it is a perspective area. Moreover, agriculture bio-business is related to bioeconomy and circular economy conception that is very significant for sustainable growth, which is receiving more and more attention. Analysed increasing value-added trends in Europe gives a basis for assumption that value added agriculture bio-business has a perspective to increase. Increasing significance of bioeconomy leads to conclusion that bio-business is also a growing prospect. In the research macroenvironment analysis for Lithuania, Poland, and Netherlands was conducted.

\section{Political environment.}

Evaluating political environment, the analysis of selected countries - Lithuania, Poland, and the Netherlands - strategical movements for bioeconomy will provide countries' preparation for agricultural bio-business development. According to Wozniak and Twardowski (2018), bioeconomy has become an important area of interest in the European Union and is associated with the implementation of various policies in the member states. Lutzeyer (2019) notes that Lithuania and Netherlands are in the process of preparing bioeconomy strategy. Poland has also started an action for bioeconomy strategy preparation (Kozyra and Cieslikowska, 2019). Many countries emphasize the importance of bioeconomy but have not yet developed a complex strategy (Wozniak and Twardowski, 2018). However, responsible authorities of selected countries, starting an action for country's strategy preparation highlight the main tasks of the direction.

In Lithuanian bioeconomy development study (Vitunskienè et al., 2017) there is emphasized that agriculture and food industries receive less attention, while fragmented attention is devoted to the industries of fisheries, wood, pulp and paper, and chemical products. It is noted that legal acts of the Republic of Lithuania provide for the following: - creating conditions for competitive and efficient agriculture and food sectors, development of export, thus increasing revenues from agriculture and alternative activities, and ensuring improving standard of living of rural residents; - supporting sustainable and balanced farming and the development of fully fledged food production considering environmental, health requirements and the improvement of quality of life in rural areas; - aiming to 
preserve soil fertility, promoting the implementation of sustainable agricultural practice by implementing advanced agricultural systems; - complying with strict policy of giving up (prohibiting) the use of genetically modified organisms in Lithuania; - taking active and ambitious measures to reduce food waste, help municipalities arrange food waste collection system and install measures allowing reducing the generation of food waste. The authors of Lithuanian bioeconomy development study (Vitunskienè et al., 2017) summarize that the development of bioeconomy in Lithuania can be stated to be mainly regulated and promoted via certain sectoral policies to this day, including policies of agriculture, forestry, fisheries, energy, environment (including waste management), development of research, innovation and biotechnology, etc.

In Poland, according to Wozniak and Twardowski (2018), there is no single, complex, and strategic document dedicated to bioeconomy. Country has strategic plans for separate areas like climate change, biotechnology, bioenergy et al. However, there are three sectors of the economy which play an important role and are incorporated to the national bioeconomy strategy, namely agriculture, agro-food processing industry and forestry. Wozniak and Twardowski (2018) note that issues related to the development of bioeconomy are incorporated in three integrated strategies, which are included in the implementation of the Strategy for the Development of the Country, which defines developmental goals for Poland up to 2020 and focuses on the increase in three areas: competitive and innovative economy, effective and robust state, and demonstration of the differences in development of the provinces. However, Poland has strategy for sustainable development of rural areas, agriculture and fisheries 2030, adopted by the Council of Ministers on October 15th, 2019, which sets these goals:

I. Increasing the cost-effectiveness of agricultural production: - creating new alternative value chains in bio-products production; - increase using renewable biological resources for new products production; - modernization of agriculture by adopting the latest technologies; - promotion of technologies aimed at minimizing consumption of natural resources; - dissemination of circular economy with special concern for using residuals of agriculture and agri-food processing.

II. Improving the quality of life, infrastructure, and the environment: - implementing proenvironmental methods of agricultural production and the use and management of agricultural byproducts; - investments for using energy resources available locally; III. Developing entrepreneurship and non-agricultural workplaces: - promotion of the use of local potentials and advantages e.g. regarding bioeconomy.

Analyzing policy actions in the Netherlands, Ministry of Economic Affairs and Climate Policy (2018) highlight some main tasks developing the bioeconomy: - circular economy. Embracing the circular economy and working on the 'biomass and food' action points in the transition agenda for the circular economy. - biomass. Mobilizing sustainable biomass and ensuring that sustainable biomass is made more easily available. - innovation. Bridging gaps in innovation, encouraging frontrunners and types of collaboration that involve both the government and the business sector (publicprivate partnerships). - support. Ensuring greater support for the bioeconomy via effective communication and by listening more closely to the wishes of society. - market demand. Developing market demand by encouraging sustainable purchasing and developing business cases.

Summarizing the analysis of political direction in selected countries, although none of analyzed countries have bioeconomy strategy, it can be assumed that Lithuania has the most favorable political environment for agriculture bio-business development as there in the strategic goals for bioeconomy development relatively much attention is paid for agricultural activities.

The authorities of Poland pay attention to different bioeconomy sectors and problems, e.g. biotechnology, bioenergy, climate change, but there is no focus on agriculture or agricultural biobusiness development. The Netherlands are more concentrated on business in the context of bioeconomy development. It also highlights the importance of innovation. Concluding, it could be assumed that Lithuania takes the first rank with the most favorable political environment for agricultural biobusiness development, the Netherlands, that are also focusing on business in the context of 
bioeconomy, are in the second position and Poland takes the third place with non-specific goals for agriculture bio-business.

\section{Economic environment.}

Analysing economic environment of selected countries, economic data analysis will provide countries' potential for agriculture bio-business development. According to the data by Lithuanian Institute of Agrarian Economics (2019), there were 968 agricultural companies and enterprises. Compared to 2014 , the number increased by $3.2 \%$. The average size of a farm by the UAA (utilized agricultural area) declared by all agricultural entities in 2018 in Lithuania was 22.7 ha. Table 3 shows detail structure of agricultural holdings by economic size in Lithuania, Poland, and Netherlands in 2016.

Table 3. Structure of agricultural holdings by economic size in Lithuania, Poland, and Netherlands (compiled by the authors based on the European Commission, 2019)

\begin{tabular}{|c|c|c|c|c|c|c|}
\hline & \multicolumn{2}{|c|}{ Lithuania } & \multicolumn{2}{|c|}{ Poland } & \multicolumn{2}{|c|}{ Netherlands } \\
\hline & Total & Percent & Total & Percent & Total & Percent \\
\hline$<4000$ EUR & 87830 & $58.4 \%$ & 661120 & $46.9 \%$ & 540 & $1.0 \%$ \\
\hline \multirow[t]{2}{*}{$<8000$ EUR } & 26330 & $17.5 \%$ & 252790 & $17.9 \%$ & 1780 & $3.2 \%$ \\
\hline & \multicolumn{2}{|c|}{ Lithuania } & \multicolumn{2}{|c|}{ Poland } & \multicolumn{2}{|c|}{ Netherlands } \\
\hline$<15000$ EUR & 16390 & $10.9 \%$ & 184700 & $13.1 \%$ & 3150 & $5.7 \%$ \\
\hline$<25000$ EUR & 6250 & $4.2 \%$ & 110260 & $7.8 \%$ & 3420 & $6.1 \%$ \\
\hline$<50000$ EUR & 6130 & $4.1 \%$ & 109160 & $7.7 \%$ & 5060 & $9.1 \%$ \\
\hline$<100000$ EUR & 3940 & $2.6 \%$ & 58940 & $4.2 \%$ & 5390 & $9.7 \%$ \\
\hline$<250000$ EUR & 2490 & $1.7 \%$ & 24480 & $1.7 \%$ & 9840 & $17.7 \%$ \\
\hline$<500000$ EUR & 590 & $0.4 \%$ & 5800 & $0.4 \%$ & 13580 & $24.4 \%$ \\
\hline$=>500000$ EUR & 390 & $0.3 \%$ & 3450 & $0.5 \%$ & 12920 & $23.2 \%$ \\
\hline Total & 150320 & $100 \%$ & 1410720 & $100 \%$ & 55680 & $100 \%$ \\
\hline UAA (ha) per holding & \multicolumn{2}{|c|}{19.5} & \multicolumn{2}{|c|}{10.2} & \multicolumn{2}{|c|}{32.3} \\
\hline
\end{tabular}

Table 3 shows the structure of agricultural holdings by economic size in Lithuania, Poland, and Netherlands in 2016. Economic size is considered as the standard output of an agricultural product (crop or livestock), abbreviated as SO, is the average monetary value of the agricultural output at farm-gate price, in euro per hectare or per head of livestock. The sum of all the SO per hectare of crop and per head of livestock in a farm is a measure of its overall economic size, expressed in euro (European Commission, 2019). The data in table reveals different features of agriculture holdings by analyzed countries. Comparing economic size, different trend between Netherlands and two other countries are evident. Lithuania and Poland have the biggest share of small agriculture holdings (less than 4000 euro) with a decreasing percent of higher economic size holdings. While Netherlands has the opposite trend where the best part is taken by the biggest holdings (from around 100000 to more than 500000 euro). In general, Poland has the biggest number of agriculture holdings - almost 1.5 million units. Lithuania has around 150 thousand holdings and Netherlands around 56 thousand agriculture holdings. The table also shows average size of agriculture holdings in analyzed countries. It reveals that Netherlands are likely to develop large holdings, what is 32.3 UAA ha per holding, Lithuania in this case takes the average position with 19.5 UAA per holding and Poland has the smallest holdings with an average of 10.2 UAA per holding. Summing up, evaluating economic environment for agricultural bio-business development in these three countries, according to economic aspects of agriculture holdings, it can be assumed that Netherlands has a favorable economic environment and a potential for developing large holdings and businesses, that can create the biggest amount of output. On the contrary, Poland has good conditions for small holdings and businesses development. Lithuania takes the average position in this context. However, analysis reveals that it has more favorable environment for small agriculture holdings and businesses development. Accordingly, it could be a direction for all these countries for potential agriculture bio-business development. 
Analysing value-added agriculture bio-business, it is important to evaluate the value added of the agricultural industry. Figure 1 shows the trend of gross value added of the agricultural industry at basic prices in Lithuania, Netherlands and Poland in the period 2008-2019, est. million euro.

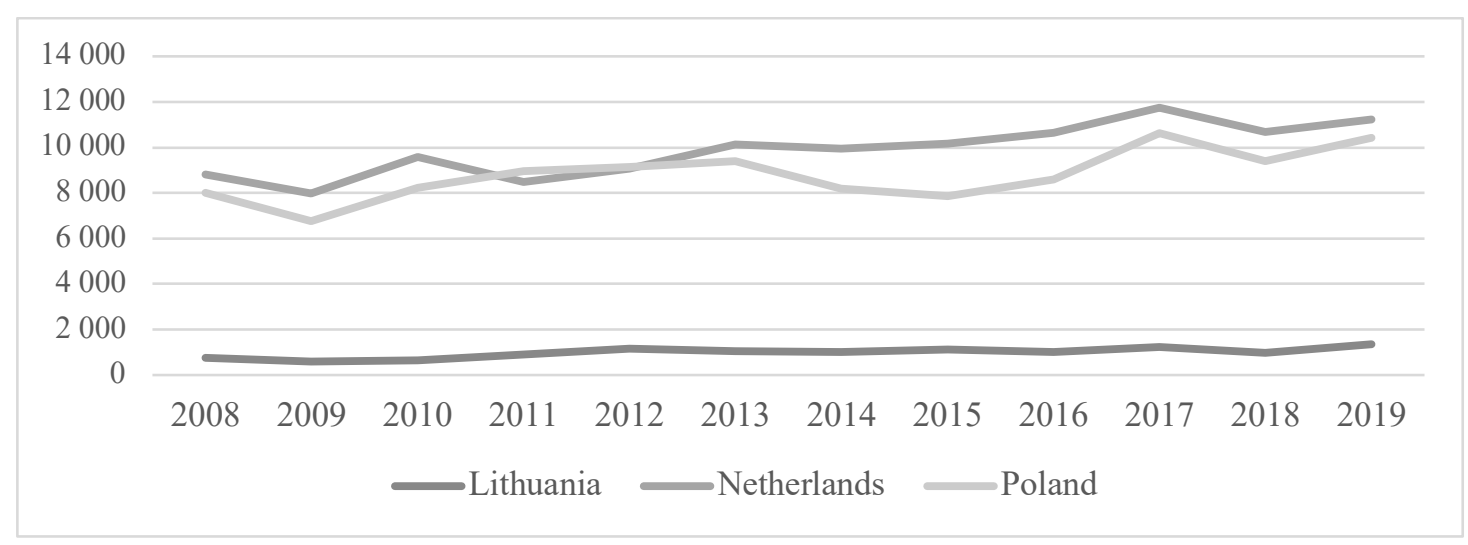

Figure 1. Gross value added of the agricultural industry at current prices in Lithuania, Netherlands, and Poland in 2008-2019, million euro (compiled by the authors based on the data of Eurostat, 2020)

Figure 1, illustrating the gross value added of the agricultural industry at basic prices in Lithuania, Netherlands and Poland reveals that in the period 2008-2019 the Netherlands had the higher gross value added, Poland took the second position, despite the period 2011-2012, when it exceeded the Netherlands, and Lithuania had the lowest gross value added in all analysed period. In general, gross value added of the agricultural industry has a trend of increase in all countries. That lead to assumption that Lithuania must give more attention on developing agricultural sector, while the Netherlands and Poland take high positions creating value added from agricultural sector. However, a trend of increase leads to conclusion that agricultural bio-business development has a potential in all analysed countries.

To evaluate value added agricultural bio-business trends, the trend of land use in Lithuania, Netherlands and Poland are analyzed (Figure 2).

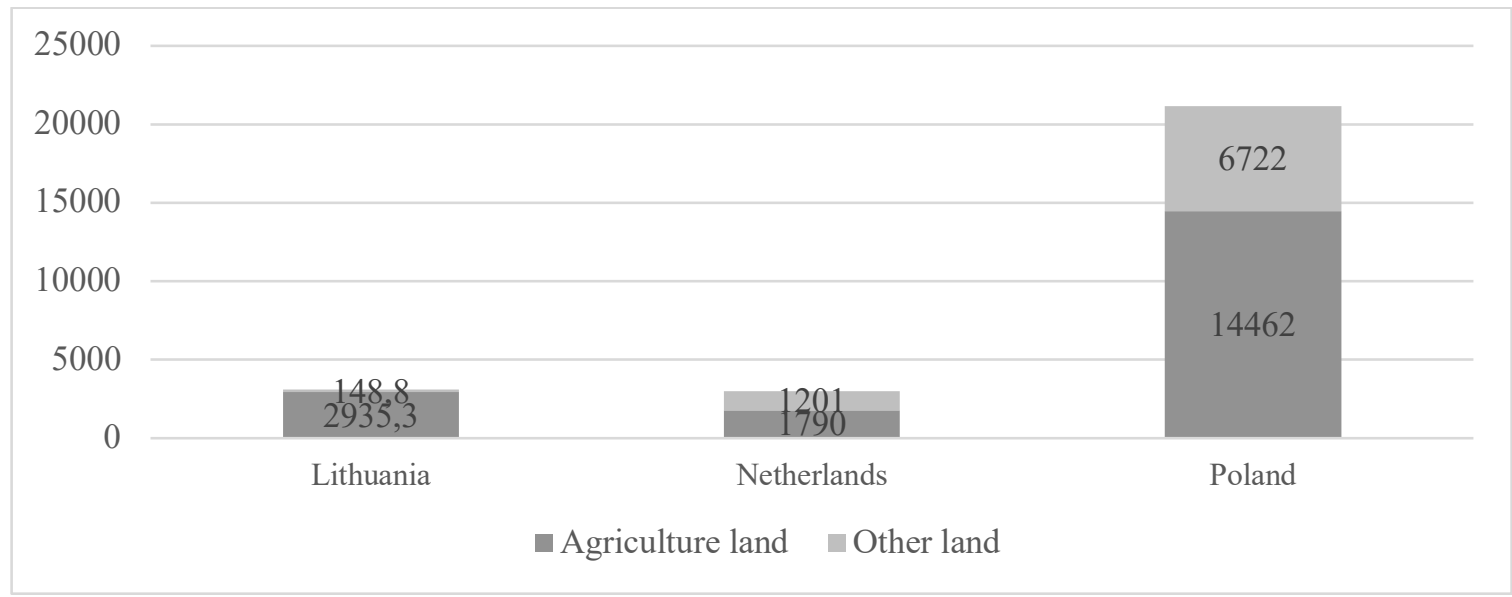

Figure 2. Land use in Lithuania, Netherlands, and Poland in 2017, thousand hectares (compiled by the authors based on the data of Food and Agriculture Organization of the United Nations, 2019) 
Poland has the most land in general and the most agriculture land, what is logical, based on the biggest area of the country. Lithuania takes the second position, comparing the amount of agriculture land and the Netherlands has the least land in general and the least agriculture land. However, evaluating the share of agriculture land and other land, Lithuania has the biggest part of agriculture land - around 95\%, the middle position is taken by Poland - around $68 \%$ and the Netherlands are still in the last position with around $60 \%$ share of agriculture land. It could be assumed that Lithuania makes the best use of its agricultural development potential. Unfortunately, the value added of the agricultural industry in Lithuania is the lowest. It could be claimed that, according to the analysis of land use, while the Netherlands and Poland still have the potential for agriculture sector development, Lithuania operates at almost full capacity. Maybe in Lithuania there is a need for some strategic decisions to more boost agriculture and to maximize its created added value (see Table 4).

Table 4. Political and economic criteria and evaluation

\begin{tabular}{|l|c|c|c|}
\hline \multicolumn{1}{|c|}{ Political and economic criteria } & Lithuania & Poland & Netherlands \\
\hline $\begin{array}{l}\text { Favorable political environment for bioeconomy (position } \\
\text { by rank) }\end{array}$ & Most positive & Least positive & Positive \\
\hline Size per holding & 19,5 UAA & 10,2 UAA & 32,3 UAA \\
\hline $\begin{array}{l}\text { Gross value added of agricultural industry (rank position } \\
\text { by Euros) }\end{array}$ & Poor & Average & Best \\
\hline Agricultural land & $95 \%$ & $68 \%$ & $60 \%$ \\
\hline
\end{tabular}

Socio-cultural environment

Bio-business industry is pushed by consumers - social factors (lifestyle changes and ecological issues) affects business development (Alava et. all., 2018). So, the impact of the social aspect of the agricultural bio-business relays to social changes and social stability (Achinas et. all., 2019). The world's population will grow rapidly and in 2050 will reach 9.7 billion. The increasing demand for food in the world will stimulate the development of the agricultural, aquaculture and processed food production sectors (Ladu et. all., 2020).

When assessing the socio-cultural environment, it is necessary to understand such aspects as: different countries' different attitudes towards working overtime, employee temperament, tendency to work finical work, religion, and traditions (Čiužienè et. All., 2016), the ability of farmers to develop their business, media's opinion about bio-businesses (D'Amato et. all., 2020). Also important is the attitude of both the state and the consumers towards new areas such as genetic modification. Regarding this question European Union lined directives, in which states that mutagenic crops and genetic modification organisms should be subject to the EU's regulatory system (Lassoued et. all., 2020). Social situation in the farming sector earn suitable consideration, so assessing specific socio - cultural aspects, it was observed that:

- The best GMO control is in Portugal, Spain, Germany, France, The Netherlands, Poland, and Slovakia (Rostoks et. al., 2019);

- Bulgaria, Croatia, Czech Republic, Estonia, Hungary, Lithuania, Poland, Netherlands, and United Kingdom are in process by 2030 to grow a bioeconomy strategy involved various bioeconomy initiatives (A sustainable ... environment, 2018).

Bellow provided main socio-cultural criteria and their evaluation for agricultural bio-business development in Lithuania, Poland, and Netherlands. 
Table 5. Socio -cultural criteria and their evaluation (some data according Giurca, 2020; A ... environment, 2018; Rostoks et. al., 2019)

\begin{tabular}{|c|c|c|c|}
\hline Socio - cultural criteria & Lithuania & Poland & Netherlands \\
\hline Notifications of GMO issues & few & few & few \\
\hline Lifestyle changes & $\begin{array}{c}\text { aging society, low birth } \\
\text { rate }\end{array}$ & youth reluctance to farm & $\begin{array}{l}\text { increasing number of } \\
\text { labor immigrants }\end{array}$ \\
\hline $\begin{array}{l}\text { Awareness about ecological } \\
\text { issues }\end{array}$ & interested in ecology & interested in ecology & interested in ecology \\
\hline Entrepreneurial spirit & $\begin{array}{c}\text { farmers are not entrepre- } \\
\text { neurial enough }\end{array}$ & farmers are entrepreneurial & $\begin{array}{c}\text { farmers are entrepre- } \\
\text { neurial }\end{array}$ \\
\hline Media view & positive & positive & positive \\
\hline $\begin{array}{l}\text { Global Biotechnology Rank- } \\
\text { ings }\end{array}$ & $32^{\text {nd }}$ & $36^{\text {th }}$ & $13^{\text {th }}$ \\
\hline
\end{tabular}

Technological environment

The main players in the global biotechnology market are the USA and Europe. In these regions there are more than 700 state-owned enterprises, and more than 200,000 employees earn about 140 billion dollars in revenue from biotechnology (Miculic, 2018). The biotechnology market is particularly receptive to research. Around 20 billion dollars is spent on them worldwide per year. The planet's biotechnology market is estimated to be worth about 400 billion euros (Garcia - Sancho, et. all., 2019). The European Commission's Lead Market Initiative goals to enable the initial adoption of innovative technologies, e.g. online presence, and technological access. (Alava et. all., 2018). Assessing specific technological aspects, it was observed that:

- Biggest thickness of bio-business facilities is in Belgium, Germany, France, and Italy (A ... environment, 2018).

- In the field of biotechnology, there are certainly excellent conditions for start-ups Rostoks et. al., 2019.

Bellow technological criteria and their evaluation for agricultural bio-business development are provided.

Table 6. Technological criteria and their evaluation (some data according Global Biotechnology Rankings; Vazques et. all., 2018)

\begin{tabular}{|l|c|c|c|}
\hline \multicolumn{1}{|c|}{ Technological criteria } & Lithuania & Poland & Netherlands \\
\hline Technological online presence & good & good & very good \\
\hline Technological access & good & good & good \\
\hline Technological investments policies of government & small & big & very big \\
\hline $\begin{array}{l}\text { Support or research and development activities by the govern- } \\
\text { ment }\end{array}$ & small & good & very good \\
\hline Global Biotechnology Rankings & $32^{\text {nd }}$ & $36^{\text {th }}$ & $13^{\text {th }}$ \\
\hline
\end{tabular}

\section{Discussion}

There are trends of high value-added multifunctional bio-business that are emerging worldwide (Vitunskienè, 2017):

- Increasing demand for biomass.

- Increasing need for reuse of bio-waste.

- Increasing use of biomass for high value-added products.

- Increasing need for CAP investment.

Analysing bio-business trends and perspectives, it is also important to pay attention to the development stages. A multifunctional bio-business must be able to be flexible at any stage. The chain of high value-added phases in agricultural multifunctional bio-business is presented (see Figure $3)$. 


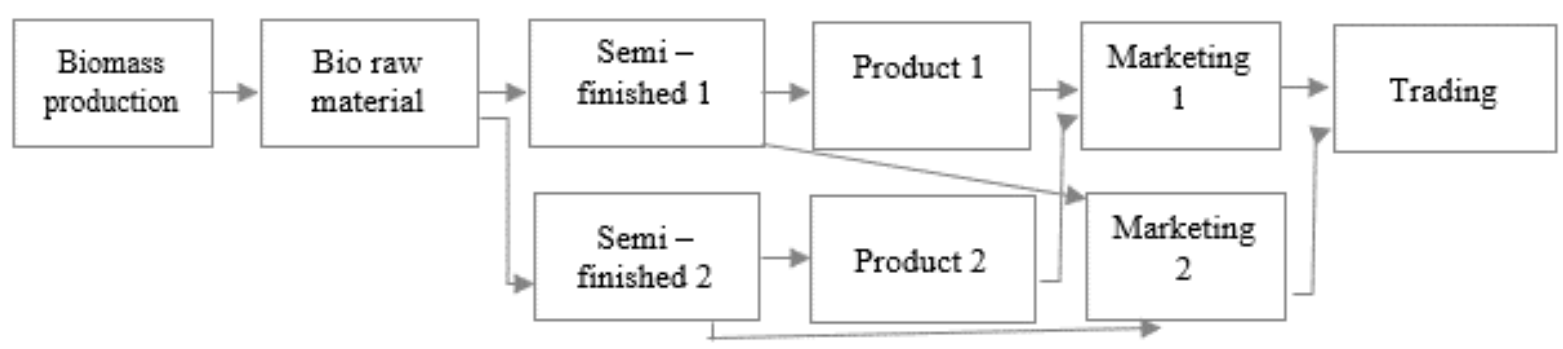

Figure 3. Phases of bio-business development

Developing of bio-business starts with biomass production, then lead to bio raw material, semi-finished products and finally reaches the final product. Then another important part is marketing and the developing chain end with trading. The whole chain must be executed sustainably and multifunctionally, not only to produce several semi-finished products or products at the same time, but also to sell any product at any stage of the chain, while offering related activities (consulting, service, etc.). Entering the international market for biotechnology can be difficult because of high levels of competitiveness, also prevail and innovation is dictated by major players. As a result, as Dobretsov (2018) claims, scientists must have business experience, marketing knowledge, and ability to sell products.

The development of bio-business from idea to final product is a long process. However, new trends also open new markets. Thus, high added value-agricultural bio-businesses should offer modern society new services and goods. And all these new markets also need new, innovative entry strategies for their business to thrive. Comparative analysis of three countries - Lithuania, Poland, and Netherlands disclose different level of conditions for bioeconomy and agricultural bio-business development. Despite different political, economic, socio-cultural and technological conditions and formed environment provide positive insights and possibilities for agricultural bio-business development.

Summing up, as the bioeconomy is becoming more significant, value added bio-business is growing as well and it is expected to grow further. Business companies have no other way but to implement the principles of bioeconomy in their activity, otherwise they risk becoming uncompetitive in the face of developing bioeconomy. It is therefore appropriate to promote investment in activities with high added value at international level; promoting the launch of new products; fostering innovation cooperation between sectors, business, and science. Agro-bio-business is a viable business area. Trends and perspectives of value-added agricultural bio-businesses could be presumed as more positive than negative in analysed European countries.

\section{Conclusions}

Bio-business is complex phenomenon, which definition depends on the research area. However, bio-business relates to natural resources and can be perceived as certain processes consisting of main stages: research, development, testing/registration, production, and marketing. Agricultural biobusiness is a viable business area. European countries statistical data analysis revealed that value added agriculture bio-business is an important direction for future value-added creation. Value added of agriculture sector is important and perspective area. Increasing value added trends in Europe let to assume that value added agriculture bio-business has a perspective to increase as well.

Development of bio-business from idea to final product is a long process. However, new trends also open new markets. Thus, high added value-agricultural bio-businesses should offer modern society new services and goods. And all these new markets also need new, innovative entry strategies for their business to thrive. Future bio-businesses can be linked to the production of high value-added products using as many times as possible treated biomass. It is noted that such businesses must be developed in a way that is sustainable. 


\section{Jolita Greblikaitè, Judita Astrovienè, Deimena Montvydaitè \\ Value-Added Agricultural Bio-Business Development in European Countries}

The main directions of bio-business could be not only the production of high value-added agricultural products, but also the search for new sources of biomass or production from bio-waste. Tendencies for agricultural bio-business development in European countries remain positive. Comparative analysis of Lithuania, Poland, and Netherlands has different macroenvironment for such business, but strategic goals are oriented to bioeconomy.

\section{References}

A sustainable Bioeconomy for Europe: strengthening the connection between economy, society and the environment. 2018. Updated Bioeconomy Strategy. - https://ec.europa.eu/research/bioeconomy/pdf/ec bioeconomy_strategy 2018.pdf 5981

Achinas, S., et. all. (2019). A PESTLE Analysis of Biofuels Energy Industry in Europe. // Sustainability 2019, 11,

Alava, R., P.; Murillo, J., M., Zambrano, R., B. (2018). PEST Analysis Based on Neutrosophic Cognitive Maps: A Case Study for Food Industry. - https://digitalrepository.unm.edu/cgi/viewcontent.cgi?article=1275\&context=nss journal

Arujanan, M., Singaram, M. (2018). The biotechnology and bioeconomy landscape in Malaysia. // New biotechnology, Vol. 40: 52-59.

Bikse, V., Lusena-Ezera, I., Volkova, T., Rivza, B. (2019). European Bioeconomy Policy and New Opportunities for Bio-Based Business Development. International Multidisciplinary Scientific GeoConference: SGEM, Vol. 19(5.3): 317-325.

Biotechnology briefings on each Scorecard country. (2019). World VIEW Guide. http://www.saworldview.com/scorecard/worldviewguide/.

Bumelis, V., A. (2018). Ar jau pasiektas biotechnologijų sektoriaus proveržis Lietuvoje? MITA conference: „Lietuvos inovaciju DNR: kaip auginti naują inovatoriu kartą?”. - https://mita.lrv.lt/uploads/mita/documents/files/renginiai/pranesimai/2018-03-08/vladas_bumelis_ar_jau_pasiektas_proverzis.pdf.

Čiužienè, K., Kaminskas, K., Petraška, A. (2016). Socialinès-kultūrinès aplinkos vaidmuo globalioje logistikoje: ekspertinis vertinimas. - https://alytauskolegija.lt/wp-content/uploads/straipsniai/Ciziuniene1.pdf

D’Amato, D., Veijonaho, S., Toppinen, A. (2020). Towards sustainability? Forest-based circular bioeconomy business models in Finnish SMEs // Forest policy and economics, Vol. 110: 101848.

- https://www.sciencedirect.com/science/article/pii/S1389934118302600

Dobretsov, S. (2018). Second GCC Marine Biotechnology conference: emerging opportunities and future perspectives // Journal of Agricultural and Marine Sciences, Vol. 23: 48- 51.

European Commission. (2019). Statistical factsheets. - https://ec.europa.eu/info/food-farming-fisheries/farming/facts-and-figures/markets/production/production-country/statistical-factsheets_en.

European Technology Platforms. (2017). The European Bioeconomy in 2030, Delivering Sustainable Growth By Addressing, The Grand Societal Challenges. - https://www.greengrowthknowledge.org/sites/default/files/downloads/resource/BECOTEPS European\%20Bioeconomy\%20in\%202030.pdf.

Eurostat. (2020). Database. - https://ec.europa.eu/eurostat/data/database.

Food and Agriculture Organization of the United Nations. (2018). Assessing The Contribution of Bioeconomy to Countries' Economy, a Brief Review of National Frameworks. - http://www.fao.org/3/I9580EN/i9580en.pdf.

Food and Agriculture Organization of the United Nations. (2019). Faostat. - http://www.fao.org/faostat/en/\#country.

Garcia - Sancho, M., Myelnikov, D. (2019). Between mice and sheep: Biotechnology, agricultural science and animal models in late-twentieth century Edinburgh. - https://www.sciencedirect.com/science/article/pii/S1369848617301814

Giurca, A. (2020). Unpacking the network discourse: Actors and storylines in Germany's wood-based bioeconomy. - https://www.sciencedirect.com/science/article/pii/S1389934118301047

Global Biotechnology Rankings. - https://www.thinkbiotech.com/globalbiotech/

Gunn, M. A. (2016). When science meets entrepreneurship: Ensuring biobusiness graduate students understand the business of biotechnology // Journal of Entrepreneurship Education, Vol. 19(2): 53-77.

Hassan, R., Marwan, A., Tawil, N., M. and Ramlee, S. (2015). Cooperative bio business model: a study at universiti Kebangsaan Malaysia // Journal of Engineering Science and Technology, Vol. 10: 81-88.

Hayward, M., Caldwell, A., Steen, J., Gow, D. et al. (2017). Entrepreneurs' capital budgeting orientations and innovation outputs: evidence from Australian biotechnology firms // Long Range Planning, Vol. 50(2): 121-133.

Horvath, B., Khazami, N., Ymeri, P., Fogarassy, C. (2019). Investigating the current business model innovation trends in the biotechnology industry // Journal of Business Economics and Management, Vol. 20(1): 63-85.

Kafarski, P. (2012). Rainbow code of biotechnology. Chemik, Vol. 66 (8): 811-816. 


\section{Jolita Greblikaitè, Judita Astrovienè, Deimena Montvydaitè \\ Value-Added Agricultural Bio-Business Development in European Countries}

Kozyra J., Cieslikowska, J. (2019). Overview of state of play on bioeconomy in Poland. Workshop "Facilitating development of bioeconomy policy - needs and gaps". - https://bioeast.eu/wp-content/uploads/2020/01/WS3_Poland.pdf.

Ladu, L., Imbert, E., Qiutzow, R. (2020). The role of the policy mix in the transition toward a circular forest bioeconomy. - https://www.sciencedirect.com/science/article/pii/S138993411830368X

Lainez, M., Gonzalez, J., M., Aguilarc, A., Velad, C. (2018). Spanish strategy on bioeconomy: Towards a knowledge based sustainable innovation // New Biotechnology, Vol. 40 (2018): 87-95.

Lassoued, L., Macall, D., M., Smyth, S., J. (2020). How should we regulate products of new breeding techniques? Opinion of surveyed experts in plant biotechnology.

https://www.sciencedirect.com/science/article/pii/S2215017X19306599

Leipold, S., Petit-Boix, A. (2018). The circular economy and the bio-based sector - Perspectives of European and German stakeholders // Journal of Cleaner Production, Vol. 201 (2018): 1125-1137.

Lietuvos bioekonomikos plètros galimybių studijos projekto pristatymo santrauka.

(2017). - http://www.lpk.lt/wp-content/uploads/2017/09/Lietuvos-bioekonomikos-pl\%C4\%97tros-galimybi\%C5\%B3studijos-pristaytmo-santrauka1.pdf

Lithuanian Institute of Agrarian Economics. (2019). Agricultural and Food Sector in Lithuania 2018. Vilnius. https://www.laei.lt/?mt=leidiniai\&straipsnis=1631\&metai=2019.

Lovric, M., et. all. (2020). Mapping forest-based bioeconomy research in Europe, - https://www.sciencedirect.com/science/article/pii/S1389934118303964?via\%3Dihub

Lutzeyer, H. J. (2019). Introduction to the European bioeconomy strategy. European Commission. SCAR-CASA Workshop. - https://scar-europe.org/images/CASA/Events/Portugal 20may2019/presentations/Hans Joerg.pdf.

Miculic, M. (2018). Biotechnology industry - Statistics \& Facts, - https://www.statista.com/topics/1634/biotechnology-industry/

Ministry of Economic Affairs and Climate Policy. (2018). The position of the bioeconomy in the Netherlands. https://gbs2018.com/fileadmin/gbs2020/documents/bioeconomy Netherlands.pdf.

Negoro, A., Kuntariningsih, A., Dewi, H., Daroini, P., et al. (2018). The usage of information and communication technology in improving bio-business performance: a case of vegetable farming in Indonesia, International Conference on Green Agroindustry and Bioeconomy. - https://www.researchgate.net/publication/328353286 The usage of information and communication technology in improving bio-business performance a case of vegetable farm-

ing in Indonesia.

Niosi, J., McKelvey, M. (2018). Relating business model innovations and innovation cascades: the case of biotechnology // Journal of evolutionary economics, Vol. 28(5): 1081-1109.

Rostoks, N., Grantina-Levina, L., Levina, B. (2019). Genetically modified seeds andplant propagating material inEurope: potential routes ofentrance and current status. - https://www.sciencedirect.com/science/article/pii/S2405844018383932

Tetslaff, J., E., Clifford, P., S. (2019). Biobusiness consulting to prepare scientists for industry careers // Nature Biotechnology, volume 37, 821-825. - https://www.nature.com/articles/s41587-019-0173-4.

The Council of Ministers of Poland. (2019). Strategy for Sustainable Development of Rural Areas, Agriculture and $\quad$ Fisheries $2030.2 \quad$ https://www.upwr.edu.pl/p/konferencje/2020/bio-based industries/05 dr_i kozyra wroclaw bbi_v2.pdf

Timmis, K., De Lorenzo, V., Verstraete, W., Ramos, J. L. et al. (2017). The contribution of microbial biotechnology to economic growth and employment creation. Microbial biotechnology, Vol. 10(5): 1137-1144.

Tyagi, P., Sengar, R. S., Kumar, A. (2018). The opportunities to develop a successful entrepreneurship and business model in biotechnology: an overview // Journal of Commercial Biotechnology, Vol. 24(3): 63-68.

Vazques, M., L., Hernandes, J., H., Hernandes, N., B., et. all. (2018). A framework for PEST analysis based on fuzzy decision maps. - https://www.revistaespacios.com/a18v39n16/a18v39n16p03.pdf

Vilmantas, V., Melnikas, B. (2014). Rinkodaros tobulinimas plètojant biotechnologijomis grindžiamą verslą. // Verslas: Teorija ir praktika Vol. 15(3): 210-219.

Vitunskienè, V. (2017). Bioekonomikos plètra Lietuvoje. - https://zum.lrv.lt/uploads/zum/documents/files/LT versija/Naujiena/Vitunskiene Bioecon 0301.pdf.

Vitunskienè, V., Miceikienè, A., Aleknevičienè, V., Čaplikas, J., Miškinis, V., Pilvere, I., ..., Ramanauskè, N. (2017). Lithuanian bioeconomy development feasibility study. - https://eimin.lrv.lt/uploads/eimin/documents/files/Inovaciijos/bioekonomikos\%20studija/Lithuanian\%20Bioeconomy\%20Study EN(1).pdf.

Woźniak, E., Twardowski, T. (2018). The bioeconomy in Poland within the context of the European Union // New biotechnology, 40, 96-102. - https://www.sciencedirect.com/science/article/pii/S1871678417300389?casa token=mPdoNYSeW3AAAAAA:GvooF8ZTQqs-uq5kOJixLqJf WsRpVVgJIY2lEYf-

u8Thde cS3ruCbu9ihwt5TnTgmegXAB1W8Q\#bib0075. 